\title{
Efficacy Of C-10 Massoialactone against-Multispecies Microbial Biofilm
}

\author{
Hasyrul Hamzah ${ }^{1(\mathbb{D})}$, Sylvia Utami Tunjung Pratiwi ${ }^{2,3(\mathbb{D})}$, Triana Hertiani ${ }^{2,3}$ (i) \\ 1 Faculty of Pharmacy, Universitas Muhammadiyah Kalimantan Timur, Samarinda, Kalimantan Timur 75124, Indonesia; \\ hh241@umkt.ac.id (H.H.); \\ 2 Department of Pharmaceutical Biology, Faculty of Pharmacy, Universitas Gadjah Mada, Sekip Utara Yogyakarta 55281, \\ Indonesia; Sylvia_pratiwi@ugm.ac.id (S.U.T.P.); hertiani@ugm.ac.id (T.H); \\ 3 Center for Natural Anti-infective Research (CNAIR), Faculty of Pharmacy, Universitas Gadjah Mada, Yogyakarta, \\ Indonesia, 55281, Sylvia_pratiwi@ugm.ac.id (S.U.T.P.); hertiani@ugm.ac.id (T.H); \\ * Correspondence: Sylvia_pratiwi@ugm.ac.id (S.U.T.P.);
}

Received: 11.06.2021; Revised: 20.07.2021; Accepted: 25.07.2021; Published: 9.08.2021

\begin{abstract}
Biofilm is a community of Microbes found in almost all habitats. They bind to the surface and become incorporated in the biomolecule-rich extracellular matrix. The matrix can fully Microorganisms are covered and rendered more immune to antibacterial agents, becoming a progressive infection source. Anti-biofilm compounds need to be discovered to deal with these biofilm-mediated infections. C-10 Massoialactone $\left(\mathrm{C}_{10} \mathrm{H}_{16} \mathrm{O}_{2}\right)$, a significant component of MassoiaaromaticaBecc. The essential oil has demonstrated that antibacterial and anti-fungal properties are possible. This study aims to see how effective C-10 Massoialactone is against multi-species microbial biofilm of Candida albicans, Pseudomonas aeruginosa, and Escherichia coli. Massoia lactone It is derived from the essential oil of Massoiaaromatica bark. To isolate and explain these compounds, researchers used preparative thin layer chromatography (TLC), gas chromatography-mass spectrometry (GC-MS), with 1D-1H nuclear magnetic resonance (NMR) analysis. The impact of horse-tail lactone on several microbial biofilms was investigated. The biofilm structure was analyzed using a transmission electron microscope (TEM) and scanning electron microscope (SEM) the biofilm structure. GCMS and NMR results revealed the presence of C-10 Massoialactone (96.59 \%). C-10 Massoialactoneshowed a dosedependent activity in inhibiting biofilm formation as well as in breaking down established biofilms. Higher concentrations of C-10 Massoialactoneare required to inhibit the mature phase of the tested biofilm. TEM and SEM analysis showed apparent cell lysis in the biofilm in the presence of C-10 Massoialactone. C-10 Massoialactone can function because of its rich potential as a new anti-biofilm drug for various microbial biofilms.
\end{abstract}

Keywords: C-10 Massoialactone; multi-species biofilm; Candida albicans; Pseudomonas aeruginosa; Escherichia coli; SEM; TEM.

(C) 2021 by the authors. This article is an open-access article distributed under the terms and conditions of the Creative Commons Attribution (CC BY) license (https://creativecommons.org/licenses/by/4.0/).

\section{Introduction}

The growing microbial growth that has developed resistance to many commonly used antibiotics, intensifies the necessity to find new anti-biofilm compounds. Biofilm is one of the common living environments for microorganisms (enter into disease-causing microorganisms). It has revolutionized microbiology and become one of the significant attention research areas of the international medical microbiology research communities [1,2]. Biofilms communities of microbes adhere to a surface and are embedded within an extracellular matrix comprised of polysaccharides, proteins, and extracellular DNA [3]. Biofilm development is described by 
different steps [4]. In these layers, cells have different characteristics from live cells that are unattached (plankton). These EPS provide an extra covering around the cells, providing a shield against various stresses [5] that are irreversibly attached to an object's surface [6]. At least an estimated $65 \%$ of all this nosocomial infection was found to involve a biofilm and estimated that about $60-70 \%$ of HAIs are biofilm-related infections associated with implanted medical devices [7]. Biofilms have been implicated in various medical device infections, including urinary catheters, central venous catheters, cardiac-implanted devices, dentures, and other prostheses [8].

As antibiotic resistance strains are emerging worldwide, there has emerged an effort towards [9]. The development of new antibacterial agents. These antibiotic-resistant biofilms are not only effective but can be successfully molded not only on human skin but also on biofilm infections of surgical instruments (such as catheters) and implants. [10], which can cause infection. In addition, studies have shown whether biofilms are included in persistent microbial infections [11,12], which creates an appropriate environment for the determination and rise of multi-drug safe strains, making them resistant to antimicrobial agents [13]. Biofilms can be found in almost all habitats that absorb water, nutrients, and surface water, such as industrial or drinking water pipes, dirt on rocks, toilets, showers, moss, or lichens trunk. Optimal sucrose level, temperature, and $\mathrm{pH}$ were useful for the formation of biofilm. Hence, alterations of these three important factors critically affect biofilm formation [14]. In nature, biofilms are composed of a variety of bacteria and fungi, algae, yeasts, protozoa, as well as a mixture of non-biological debris and corrosive products [15]. Specific structure and nature of biofilms stimulate a constant up- and down-regulation of certain genes, followed by metabolism reduction and diversification of bacterial cells functioning [16]

The microbial composition of dental biofilms, for example, includes over 600 species of bacterial, fungal, and archaea [17]. The growth of biofilms may provide better opportunities than the growth of single cells to adapt to changing conditions organisms collectively. For single-species biofilms, previous studies have shown that the developmental outcome of biofilms is significantly affected by the selected growth medium [18]. The tolerance to environmental stress is likely facilitated by the EPS matrix produced by microbial cells in the biofilms and perhaps by the physiological adaptation of individual cells to heterogeneous microenvironments within the complex architecture of biofilms [19]. Microbes in biofilm states are a major concern since they are much more tolerant to antibiotics and disinfectants in this conformation than in a planktonic state [20].

Most studies have been done targeted at the single species microbial biofilms. However, little attention has been paid to medically relevant multi-species microbial (polymicrobial). Polymicrobial biofilms are associated with chronic infections of various sites in the body [21]. Polymicrobial infections can display a more complex pathology than single-species infections In biofilm formation [22]. The polymicrobial nature of many human infections adds a further layer of complexity [23]. For biofilms related for human health, divided into two main influencings factor: the types of microorganisms participate and the reaction of the host, will happen in turn affect the progress of microorganisms from time to time. This high-level between interactions Microbial species and hosts are repetitive processes that help develop acute-phase infections into chronic pathogenic biofilms. Therefore, long-term infection studies are needed to understand the incidence of longitudinal cascades that ultimately lead to infection of biofilms pathogenic [24]. 
The microbial species in multi-species biofilms vary widely depending on their environment. Researchers must Identify species in multi-species biofilms to be able to manipulate and understand the function of biofilms. Synergistic interactions in the multispecies biofilm have an impact on the distribution of bacteria and overall biomass produced. The multi-species biofilm businesses affect the biofilm's physiological function by increasing resistance, virulence, or degradation of pollutants essential for human health and activities [24]. Biofilm as a microbial defense is relatively more difficult to eradicate by antibiotics. Furthermore, the current antibiotic therapies showed very limited effectiveness compared to the biofilm infection [25]. Thus, the pathogenicity of microbes in biofilm may cause serious problems for human health [26], and limited therapeutic options [27]. Many studies emphasize that microbial interactions in mixed infections can accelerate and worsen disease progression [28].

With 17,000 islands, Indonesia is the nation with the most islands in Southeast Asia's equatorial seas. Indonesia is considered to be the second most prosperous country in biodiversity, second only to Brazil. It has a unique natural ecosystem with abundant animal and plant capital and a significant variety of animals that are only present on the islands. The total number of known species is 1.46 million. In terms of its wealthy natural legacy, social foundation, and populace, Indonesia have a critical part within the homegrown pharmaceutical industry. Numerous educate in Indonesia, particularly government offices such as the Service of Wellbeing and the Indonesian Nourishment and Medicate Organization, then many wellknown universities, actively participate in research on natural products, and particular drugs and pharmaceuticals. However, few studies have investigated the anti-biofilm efficacy of Indonesia's natural resources [29].

Massoiaaromatica (synonym: Cryptocaryamassoy (Oken) Kosterm) is an evergreen tree that has a place in the Tree family. This tree is medium in an estimate and can develop up to $15 \mathrm{~m}$ with territory to develop in rainforests with a height of $400 \mathrm{~m}$ to $1000 \mathrm{~m}$. This plant could be an uncommon plant that lives in Indonesia, with a distribution area, especially in Maluku and West Papua [30]. Locals usually use horse-tail wood as a building material. In making batik cloth, the bark is usually used to become a ruddy color in batik manufacturing. In the Suram area, Maluku, Indonesia, the anglers, as a rule, utilize masoyi clears out to fill their pads, which are useful for warming themselves, especially the head when going out to sea [31]. Women in Java and Bali usually use calla bark powder to formulate and then also made into a treatment called bobory, typically utilized to form the body warm by greasing up the body, and is utilized particularly on cold and stormy days. As a result, the body feels warmer, and it is believed by the public to help relieve the symptoms caused by various diseases. They have been used several times for generations in their respective societies [32]. It is known that Massoia bark also has a sweet smell like coconut, and this bark can be distilled by steam and produces Massoia bark oil, which is used as a flavor raw material in fragrance manufacturing [33].

Previous research cited that calla lily oil is historically used to deal with runs, stomach issues, fever, tuberculosis, muscle torment, complications and diligent obstruction, vaginal release, fever, and hostility to fiery drugs. It is also believed that the calla lily oil has anti-insect and anti-fungal effects because canoes and boats made of Masu wood are known to have the effect of resisting insects and fungi $[31,34,35]$. So far, there is very little scientific research on the health effects of calla lily oil. Therefore, in modern medicine, the mechanism by which Masoi oil's effectiveness is not widely known. Several studies have shown that horse-tail wood 
can play an anti-irritant effect (by moisturizing capillaries) and aromatics (aroma substances used in fragrance mixtures). A study by Widowati and Pudjiastuti [36] talked about infusion (water decoction), horse-tail pores, and skin has analgesic properties (ache relievers). Another have a look at with the aid of using Sa'roni and Adjirni [37] confirmed that the bark of horsetail additionally has anti-inflammatory activity.

Our previous studies have shown this in addition to the ability to inhibit plankton growth and biofilm formation. Aromatic essential oils can also destroy Pseudomonas aeruginosa (P. aeruginosa) PAO1, Staphylococcus aureus (S. aureus) Cowan I, and white Candida albicans (C. albicans) ATCC 10231 [38, 39]. The most effective compound of Sargassum oil C-10 Massoialactone was isolated and screened for its anti-biofilm activity against a variety of microbial biofilms in the experiments reported here.

\section{Materials and Methods}

\subsection{Plant material.}

Provide three kilograms of M. aromatic stem bark from Nabire Regency, West Papua, Indonesia. Voucher specimens were identified and stored in the Department of Pharmacy Biology, Faculty of Pharmacy, Gajamada University. Steam hydrodistillation is used to extract mineral oil. Anhydrous sodium sulfate (Na2SO4) was used to dry the oil samples, which were stored in tightly closed dark glass bottles, and stored at $4{ }^{\circ} \mathrm{C}$.

\subsection{Planar chromatographic separation and analysis.}

In this case, chromatography is utilized a $10 \times 20 \mathrm{~cm}$ silica gel 60 F254 aluminum lean layer chromatography (TLC) plate (Merck, Germany). Before use, heat the plate at $120^{\circ} \mathrm{C}$ for 3 hours preprocessing. Without this procedure, the adsorbent layer will be partially detached during soaking. Obtain eugenol sample in its pure form, cinnamaldehyde and1,8-cineole utilized as guidelines from Sigma Aldrich, dissolve them in toluene to make a solution contained $1 \mu \mathrm{L} / 30 \mu \mathrm{L}$, and apply $3 \mu \mathrm{L}$ of the solution to $10 \times 20 \mathrm{~cm}$ TLC silica gel F254 type plate, using a Minicaps capillary pipette (West Germany). For the essential oil solution, dissolve $100 \mu \mathrm{l}$ in $1 \mu \mathrm{mL}$ ethanol, and then apply $5 \mu \mu \mathrm{l}$ of the solution on a $10 \times 20 \mathrm{~cm}$ TLC silica gel F254 plate type equipped by Minicaps capillary pipette. Where the beginning line position is $1.0 \mathrm{~cm}$ from the foot and $1.0 \mathrm{~cm}$ from the cleared out, apply to the standard for most components of the basic oil on the TLC plate, close to the basic oil spots. After the sample was applied, the TLC plate is developed together on a previously optimized cellular phase. It is recommended to use toluene: ethyl acetic acid derivation (93:7) as the versatile stage [40]. This development model uses rising chromatography in a saturated double cell chamber (Camargue, Switzerland). On TLC division, everything was carried out at room temperature, to be specific $\left(20^{\circ} \mathrm{C}\right)$. For the bioautographic test, the solvents utilized within the TLC imaging framework are too tried.

At that point, after chromatographic division, taken after by the permeable layer, it is dried utilizing a broiler at $90^{\circ} \mathrm{C}$ for 5 minutes to dispense with the dissolvable. The liquor vanillin-sulfuric corrosive reagent is utilized to imagine or show isolated compounds. That created a layer submerged within the reagent and warmed at $100^{\circ} \mathrm{C}$ for 5 minutes. Identify based on the esteem of Rf (hysteresis calculate): of the proportion, separate traveled by the center of the spot to the separate traveled by the front dissolvable and the standard color. 
Parallel preparing of TLC plates for bioautography without utilizing reagents for the last improvement [40, 41].

\subsection{Bioautography analysis}

Diffusion on agar or touch For bioautography research, bioautography is used. Pseudomonas aeruginosa was cultured in $100^{\circ} \mathrm{mL}$ Luria Bertani (LB) broth overnight at $28^{\circ} \mathrm{C}$ for $24^{\circ} \mathrm{h}$ in a shaker incubator until the optical density $(600 \mathrm{~nm})$ was 1.0 or higher. Using fresh LB to OD600 $=0.1$, dilute the bacterial suspension, which is the equivalent of using $1 \times 10^{8}$ colony-forming unit (CFU) / $\mathrm{mL}$.

Spread $100 \mu \mathrm{L}$ of microbial culture samples on $15 \mathrm{~mL}$ of LB agar in a petri dish. After the agar is solidified, place the unfolded chromatographic plate face down on the inoculated agar layer and put it at $40^{\circ} \mathrm{C}$ for 24 hours to permit it to diffuse. After that brood, the chromatography plate was expelled. At that point, the agar layer was hatched at $37^{\circ} \mathrm{C}$ for 24 hours. Where the compound spots diffuse into the agar, a restraint zone is watched on the surface of the agar. The straightforward radiance shows the antibacterial action within the test on the agar surface where the separated compound is shown. The Rf esteem of the hindrance zone is measured by the distance of the substance within the separate traveled by the dissolvable [42].

\subsection{Isolation of M. aromatica oil active compound.}

According to what has been depicted over, by checking the fundamental oil over the introductory range of the line (checking on the plate), the TLC separation of the preparative aromatic oils was performed on a 10×20 performed cm silica gel 60 F254 aluminum sheet TLC plate. The visualization uses UV254 instead of staining reagents. This area (band) showed an $\mathrm{Rf}$ value equal to the $\mathrm{Rf}$ of the marked pressure region and is cleaned with a spatula carefully. Then, the loose silica was transferred to a glass funnel with glass wool, and ethyl acetate was poured into it as a solvent as the mobile phase. The eluted divisions were collected, dried utilizing SpeedVac, broken up in ethanol, encouraged to be analyzed by TLC, and watched beneath UV254. GC-MS investigation was Getting subtle elements around the chemical composition of the eluted divisions was too done.

\subsection{Gas Chromatography-Mass Spectrometry (GC-MS) analysis.}

According to the method of $\mathrm{Wu}$, et al. [42], GC-MS was used to analyze a separated fraction of aromatic essential oil. The GC-2010 gas chromatograph (Shimadzu, Japan) was prepared with a GC-MS-QP2010 Additionally mass spectrometer (Shimadzu, Japan). Utilize an Agilent J\&W DB-1 column (30 m long, $0.25 \mathrm{~mm}$ distance across, $0.25 \mu \mathrm{m}$ film thickness, Agilent) for isolating and splitting injectors. The autosampler injected $1.0 \mathrm{~mL}$ of a diluted sample (1/100 in ethyl acetate, $\mathrm{v} / \mathrm{v})$ in part mode (1/153). The stove temperature is set from $70{ }^{\circ} \mathrm{C}$ to $230^{\circ} \mathrm{C}$ with a speed of $5^{\circ} \mathrm{Cml}-1$ Helium, which is utilized as the carrier gas. The compounds recognized were based on comparing their mass range with the mass spectra recorded within the MS NIST (National Founded of Measures and Innovation) library database 12, NIST62, and WILY229. The crest zone normalization was utilized to quantitatively analyze each portion of essential oil (expressed as a percentage of area). Under isothermal conditions $\left(700^{\circ} \mathrm{C}\right)$, dead time and Kovaz retention index were calculated. 


\subsection{NMR analysis.}

Perform 1H-NMR (nuclear magnetic resonance) spectroscopy to learn more about the composition of the isolated active drug. The Bruker DRX 500 was used to capture the NMR spectrum (1H: $500 \mathrm{MHz}, 13 \mathrm{C}: 125.77 \mathrm{MHz}$ ). In a 5mm NMR tube, dissolve the divided fraction $(20 \mathrm{mg} / 1.0 \mathrm{~mL})$ in $\mathrm{CDCl} 3$, and use the solvent signal for spectral calibration $(1 \mathrm{H}$ at $7.26 \mathrm{ppm})$.

\subsection{Biofilm formation inhibition and biofilm eradication assay In Vitro.}

Microbial strains tested were aliquoted $\left(100 \mu \mathrm{L}, 5 \times 10^{5} \mathrm{CFU} / \mathrm{mL}\right.$ approximately) through the wells of a 96-well microtiter plate that is black. Serial two-fold dilutions of the isolated compounds (starting from $100 \mu \mathrm{g} / \mathrm{mL}$ ) Each positive control medication is made in the plate itself. Each bacterial strain often requires a growth control and a sterile control. To prevent evaporation during the incubation period, they applied clean water to all perimeter walls. Cover the plate, seal it in a plastic bag, and incubate at $37^{\circ} \mathrm{C}$ for 48 hours under a standard atmosphere. Tested the capability of isolated compounds to inhibit biofilm formation, and results were estimated using the MTT colorimetric method as described below.

The biofilm was measured by utilizing the 3-(4,5-dimethyl-2-thiazolyl)-2,5-diphenyl$2 \mathrm{H}$-tetrazolium bromide (MTT) lessening handle. After incubation, remove the bacterial suspension and add $150 \mu \mathrm{LMT}\left(5 \mathrm{mg} / \mathrm{mL}\right.$ in PBS) for $2 \mathrm{~h}$ at $37^{\circ} \mathrm{C}$. After recoloring, Remove the MTT solution and 2001 of dimethyl sulfoxide (DMSO) from each well and instantly pour them into the well to dissolve the formazan crystals that have developed. Incubate at room temperature for 15 minutes. The tetrazolium salt can be reduced to water-insoluble purple forma maz products by microorganisms with active electron transport systems. Dimethyl sulfoxide (DMS) is a chemical compound that is used to make Microplate Reader 550 (BioRad) was used to test the color strength of the dissolved formazan maz at a wavelength of $550 \mathrm{~nm}$ ) [43]. Calculate the least biofilm inhibitory concentration (MBIC) and least biofilm expulsion concentration by subtracting the absorbance value of the medium regulation from the value of the test well (MBEC). The concentrations of compounds that cause a 50\% diminishment in absorbance compared to a control biofilm created by microbial strains within the nonappearance of antimicrobial drugs are $\mathrm{MBIC}_{50}$ and $\mathrm{MBEC}_{50}$ [44]. The biofilm was grown in the wells of a microtiter plate at $37^{\circ} \mathrm{C}$ for 48 hours to assess the effect of the test compound on the preformed microbial biofilm. In each microtiter plate well, pour $100 \mathrm{~L}$ of uniform cell suspension $\left(10^{5}\right.$ cells $\left./ \mathrm{mL}\right)$ in TSB medium and incubate for 48 hours at $37^{\circ} \mathrm{C}$. Aspirate the medium after the biofilm has shaped and discarded the non-adh.

\subsection{Biofilm structure documentation using SEM and TEM.}

Multi-species biofilms are grown in sterile, uncoated $13 \mathrm{~mm}$ distance across plastic magnifying instrument coverslips in uncoated 24-well polystyrene cell culture plates (IWAKI) (Nunc, Weiss Baden, Germany). After 48 hours of incubation under aerobic conditions, The biofilm was carefully washed in PBS before solidified for 24 hours in a glutaraldehyde arrangement containing 2.5 percent glutaraldehyde. The coverslips were dehydrated in a graduated ethanol sequence after being washed with $0.1 \mathrm{M}$ sodium acetic acid derivation buffer (pH 7.3). The cover glass was then vital dried with $\mathrm{CO}_{2}$, gold-sprayed (thickness around 10 $\mathrm{nm})$, and analyzed with a Zeiss DSM 960A electron magnifying lens. 
In order to observe the influence of isolated compounds of plant extracts on the morphology of biofilms, transmission electron microscopy (TEM) was performed on the microbial biofilms treated with C-10 Massoialactone. Using the standard biofilm protocol described, the biofilm was grown on cover glass in a 6-well plate. Resuspend the biofilm for 1 hour at room temperature a 2 percent paraformaldehyde-2.5 percent glutaraldehyde arrangement in $100 \mathrm{mM}$ PBS (pH 7.4). After that, the tests were implanted in $2 \%$ moo softening point agarose, washed in PBS, and settled in $1 \%$ tetroxide for 1 hour. The sample was then extensively washed in purified water $(\mathrm{dH} 2 \mathrm{O})$ before being stained for 1 hour with a 1 percent uranyl acetate aqueous solution. After washing several times in $\mathrm{dH} 2 \mathrm{O}$, After being dehydrated in a series of ethanol gradients, the samples were embedded in Eponate 12 resin. Using a Leica Ultracut UCT microtome, cut $95 \mathrm{~nm}$ bits, stain them with uranyl acetic acid derivation and lead citrate, and observe them directly with a JOEL CO-Japan JEM 100 transmission electron microscope running at $80 \mathrm{kV}$.

\section{Results and Discussion}

\subsection{TLC profile and Bioautography assay of M. aromatica oil.}

The basic oil surrender is 0.5 percent (w/w). To isolate aromatic aromatic methane essential oil, a TLC curve was used with toluene: ethyl acetate: 93: 7 and anisaldehyde sulfuric acid as the stain solution (Table 1). The majority of oil components is calculated using available data sources and GC-MS analysis (Table 2). Horse-tail lactone (77.06\%) was found to be the key component in $M$. aromatica oil among the compounds recognized.

Figure 1. TLC profiling of M. aromatica esssential oil.

\begin{tabular}{|c|c|c|c|c|}
\hline Rf & Color & UV2 & & UV366 \\
\hline 0.81 & Dark blue & Rf 0.81 & & 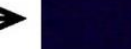 \\
\hline 0.41 & Blue & Rf $0.41-$ & & \\
\hline 0.25 & Purple & Rf $0.25-$ & & \\
\hline & & & massoia oil & \\
\hline
\end{tabular}

Table 1. Chemical composition of the essential oil from the bark of $M$. aromatica

\begin{tabular}{c|l|c|c} 
No. & \multicolumn{1}{|c}{$\begin{array}{c}\text { Compound } \\
\text { Retention Time } \\
(\mathbf{m i n})\end{array}$} & Peak Area (\%) \\
\hline 1 & L-Linalool \$\$ & 10.491 & 1.95 \\
\hline 2 & Alpha Copaene & 15.243 & 2.94 \\
\hline 3 & Beta Elemene \$ & 15.467 & 1.24 \\
\hline 4 & Alloaromadendrene \$ & 16.411 & 3.17
\end{tabular}




\begin{tabular}{c|l|c|c}
\hline \multicolumn{1}{c|}{ Compound } & \multicolumn{1}{|c|}{\begin{tabular}{c}
\multicolumn{1}{|c|}{ Retention Time } \\
$(\mathbf{m i n})$
\end{tabular}} & Peak Area (\%) \\
\hline 5 & $\begin{array}{l}\text { 5-Hydroxy-2-Decenoic Acid Lactone \$\$ 2H-Pyrane-2-one, 5,6- } \\
\text { dihydro-6-penthyl-, (R)-(CAS) (-)-Massoia lactone }\end{array}$ & 17.242 & 77.06 \\
\hline 6 & $\begin{array}{l}\text { Cyclopentane, 1,1'-ethylidinebis-\$ Ethane, 1,1-dicyclopenthyl-\$\$ } \\
\text { 1,1-Dicyclopenthylethane }\end{array}$ & 19.591 & 8.54 \\
\hline 7 & Benzyl Benzoate & 20.443 & 5.11
\end{tabular}

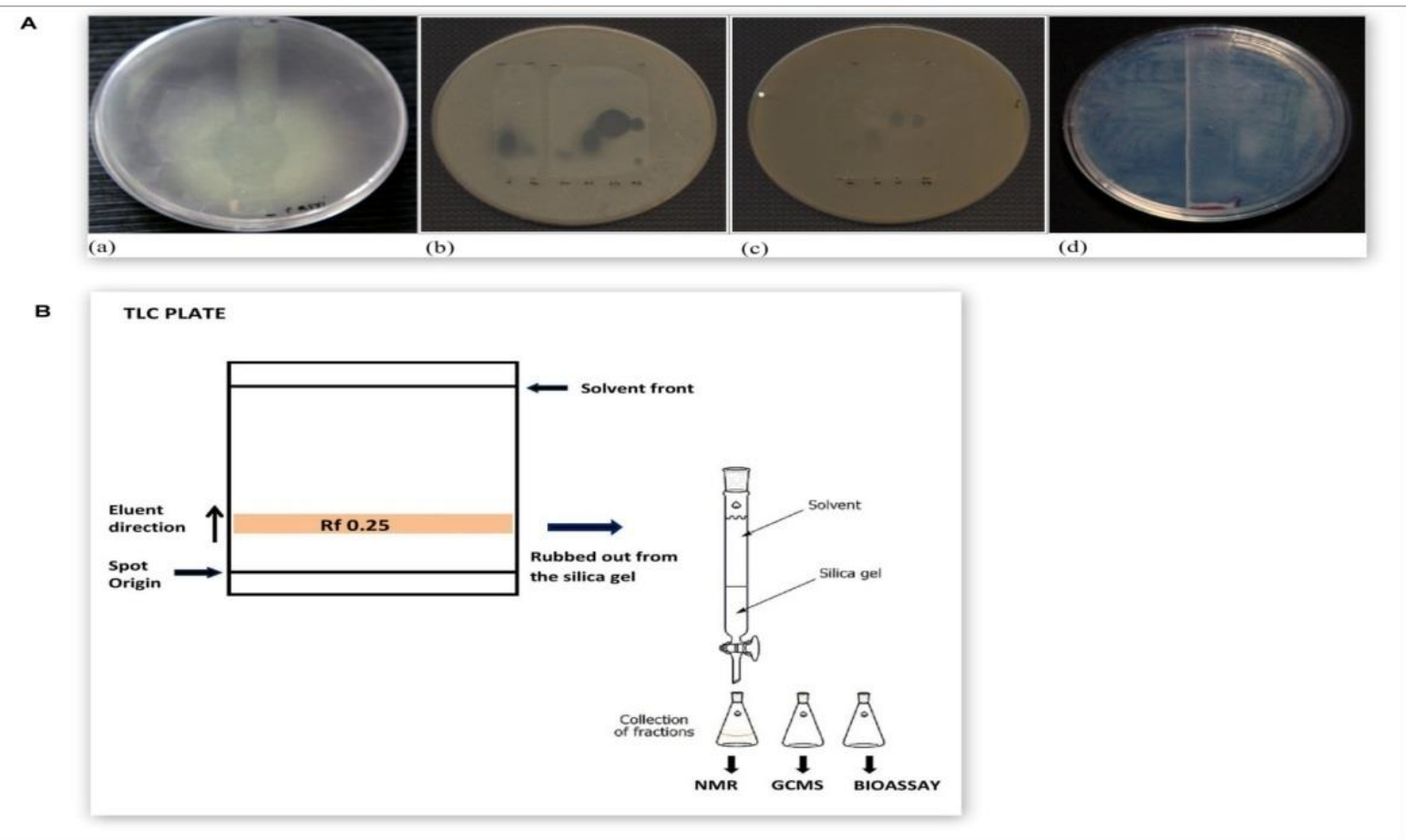

Figure 2. Isolation of $M$. aromatica oil's active compound. (A) Bioautography analysis of (a) M. aromatica oil on $C$. violaceum WT plate, (b $M$. aromatica oil, isolated $M$. aromatica oil active compound (Mlact), cinnamaldehyde and eugenol on C.albicans 10231 plate, on P. aeruginosa PAO1 plate, and (d) on S. aureus Cowan I plate. (B) Scheme of isolation procedure for $M$. aromatica active compound using preparative TLC.

The bioautography of the aromatic Monaco essential oil using Pseudomonas aeruginosa PAO1 is seen in Figure 1. This process, which is similar to disc detection and is used in conjunction with TLC isolation, is similar to disc detection. It's a fast and easy way to see whether essential oil components have antibacterial activity. Using the contact bioautography procedure, microorganisms diffuse from the TLC plate to the vaccinated agar plate. Pseudomonas aeruginosa bioautography shown that the component with an Rf esteem of 0.25 tended to be the key component mindful of the oil's natural properties. Then, to isolate the active compound, conduct TLC preparative analysis on the compound.

\subsection{Isolation of M. aromatica oil active compound, GC-MS, and NMR analysis.}

A GC-MS study was performed to learn more almost the chemical structure of the basic oil of the fragrance tree. The chemical structure and GC-MS spectrum of B. aromatensis essential oil are seen in Table 1 and Figure 2. Similarly, sargassum lactone was found to be the essential compound (77\%).

The active compounds of Mycoplasma aromatica essential oil are separated using preparative thin-layer chromatography. Three isolated compounds $(24,22$ and $32 \mathrm{mg} / \mathrm{mL})$ were obtained as a result. At an Rf value of 0.25 , TLC analysis of the segregated compound indicated a dark blue spot. GC-MS was used to analyze the chemical structure of the isolated substances. 


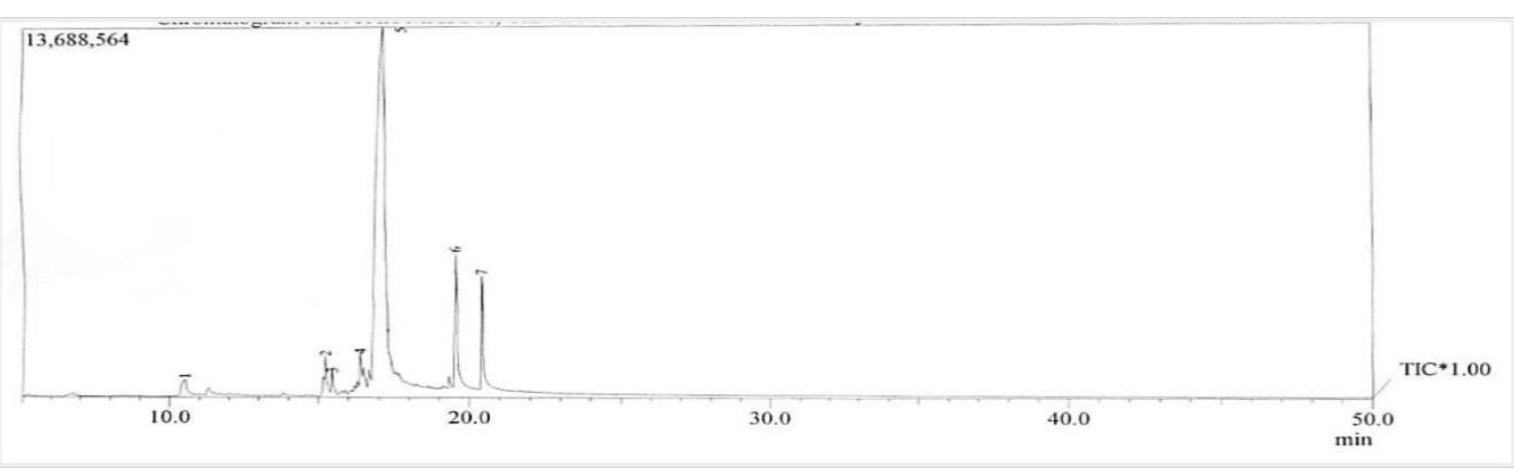

Figure 3. GC-MS profile of $M$. aromatica essential oil. The indicated compounds in the chromatograms are shown in Table 1.

Table 2 and Figure 4 show that the 5-hydroxy-2-decenolide \$2H-pyran-2-one, 5,6Dihydro-6-pentyl-, (R)-(CAS), (-)-masoialactone $\mathrm{C}_{10} \mathrm{H}_{16} \mathrm{O}_{2}$ was separated from aromatic wood balsam oil) by preparative chromatography taken after by GC-MS investigation (94\%. In our previous study, we used a TLC densitometer to determine the content of C-10 lactone in horsetail oil at the maximum wavelength of $211 \mathrm{~nm}$. The content of C-10 Massoialactone in 1 percent $\mathrm{v} / \mathrm{v}$ horse-tail oil was previously seen to be 0.55 percent $\mathrm{w} / \mathrm{v}^{35}$.

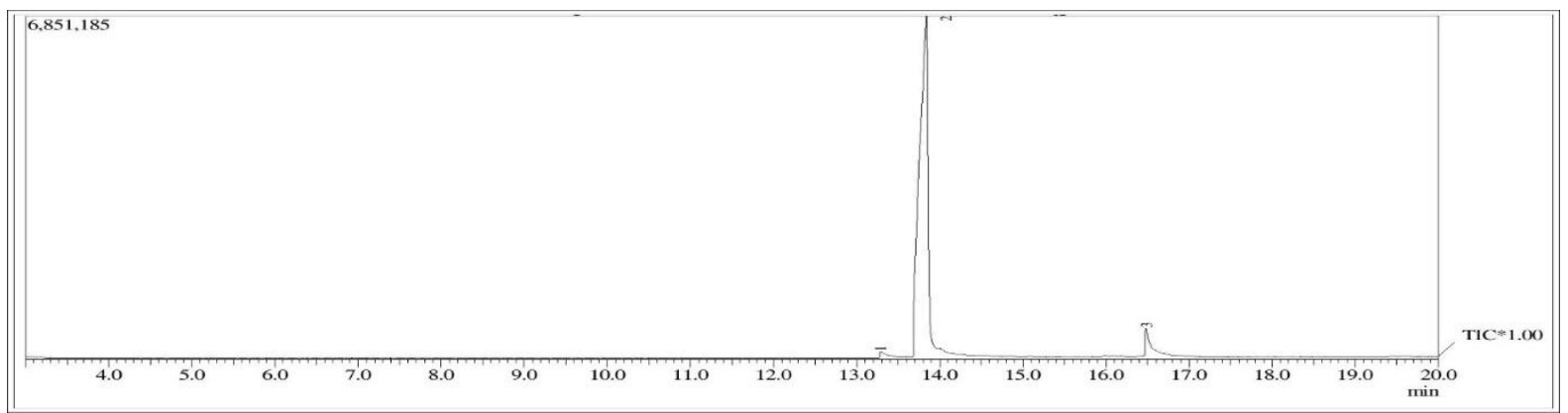

Figure 4. GC-MS profile of $\mathrm{C}_{10} \mathrm{H}_{16} \mathrm{O}_{2}$ massoia lactone isolated from massoia essential oil. The indicated compounds in the chromatograms are shown in Table 2.

Table 2. Major chemical constituents of $M$. aromatica essential oil as identified by GC-MS

\begin{tabular}{c|c|c|l|c|c} 
Peak & $\begin{array}{l}\text { Retention } \\
\text { time (Rt) }\end{array}$ & Area & $\begin{array}{l}\text { Area } \\
(\%)\end{array}$ & $\begin{array}{l}\text { Similarity } \\
\text { index (SI) }\end{array}$ & Chemical Component \\
\hline 2 & 25.346 & 156590945 & 92.05 & 94 & $\begin{array}{c}\text { 5-Hydroxy-2-Decenoic acid lactone } \\
\left(\mathrm{C}_{10} \mathrm{H}_{16} \mathrm{O}_{2} \text { Massoia lactone }\right)\end{array}$ \\
\hline 3 & 29.961 & 10522375 & 6.19 & 86 & $\begin{array}{c}\text { 5-Hydroxy-2-Decenoic acid lactone } \\
\left(\mathrm{C}_{10} \mathrm{H}_{16} \mathrm{O}_{2} \text { Massoia lactone) }\right.\end{array}$
\end{tabular}

*The compound obtained was predicted to be a 5-Hydroxy-2-Decenoic acid lactone (Massoia lactone) derivate with a higher boiling point and have the same fragmentation as Massoia lactone.

To ensure that the structure was obtained, 1D 1H-NMR elucidation was performed. The gotten H-NMR range (Figure 4) affirmed the proposed structure proposed by GC-MS, namely $\mathrm{C}_{10} \mathrm{H}_{16} \mathrm{O}_{2}$, which was further validated by comparison with data reported on $\mathrm{CDCl} 3$ simultaneously by Siminiatto [45] and Harbinduand Kumar [46].

The infrastructure is in place (Table 4). The resonance peak in the high field area supporting $11 \mathrm{C}$, which supports the propane substituent, confirms the existence of the aliphatic chain. At 4.40-4.46 $(1 \mathrm{H}, \mathrm{m})$, which reflects the H-containing chiral carbon instantly adjoining to the lactone portion, there's a alter to the lower field layer (H-6). With a coupling steady of $9.75 \mathrm{~Hz}$, the cis-ortho $\mathrm{H}-\mathrm{H}$ coupling of olefins was watched between the resonances of $\delta 6.87-$ 6.92 and $86.03-6.06$. These observations confirm the presence of unsaturated lactones. The 
resonance peak is further broken due to the inclusion of neighboring methylene groups (H-5). Because it can be said that $\mathrm{R}$ isomers exist in nature, this restriction is designated as (Figure 6).

Table 3. NMR data of isolate in comparison to (-)-Massoia lactone $\left(\mathrm{C}_{10} \mathrm{H}_{16} \mathrm{O}_{2}\right)$.

\begin{tabular}{|c|c|c|c|c|c|c|}
\hline \multirow{3}{*}{$\begin{array}{l}\text { Atom } \\
\text { No. }\end{array}$} & \multicolumn{2}{|c|}{ Isolate $^{\text {a) }}$} & \multicolumn{2}{|c|}{ (-)-Massoia lactone $\left(\mathrm{C}_{10} \mathrm{H}_{16} \mathrm{O}_{2}\right)^{\mathrm{b})}$} & \multicolumn{2}{|c|}{ (-)-Massoialactone $\left(\mathrm{C}_{10} \mathrm{H}_{16} \mathrm{O}_{2}\right)^{\mathrm{c})}$} \\
\hline & \multicolumn{2}{|l|}{${ }^{1} \mathrm{H}$} & \multicolumn{2}{|l|}{${ }^{1} \mathrm{H}$} & \multicolumn{2}{|c|}{${ }^{1} \mathrm{H}$} \\
\hline & $\delta$ & $\begin{array}{l}\text { Integration, } \\
\text { multiplicity, } J \text { in } \\
\mathrm{Hz}\end{array}$ & $\delta$ & $\begin{array}{l}\text { Integration, } \\
\text { multiplicity, } \\
J \text { in } \mathrm{Hz}\end{array}$ & $\delta$ & $\begin{array}{l}\text { Integration, } \\
\text { multiplicity, } J \text { in } \mathrm{Hz}\end{array}$ \\
\hline $\mathrm{H}-4$ & $6.87-6.92$ & $\begin{array}{l}1 \mathrm{H}, \mathrm{ddd}, J=9.75 \\
5.4,4.4\end{array}$ & $6.78-6.83$ & $1 \mathrm{H}, \mathrm{m}$ & $\begin{array}{l}6.87- \\
6.90 \\
\end{array}$ & $1 \mathrm{H}, \mathrm{m}$ \\
\hline H-3 & $6.03-6.06$ & $\begin{array}{l}1 \mathrm{H}, \mathrm{ddd}, J=9.75 \\
1.25,1.4\end{array}$ & $5.93-5.97$ & $1 \mathrm{H}, \mathrm{m}$ & 6.04 & $1 \mathrm{H}, \mathrm{d}, J=10$ \\
\hline H-6 & $4.40-4.46$ & $1 \mathrm{H}, \mathrm{m}$ & $4.32-440$ & $1 \mathrm{H}, \mathrm{m}$ & $\begin{array}{l}4.41- \\
4.45\end{array}$ & $1 \mathrm{H}, \mathrm{m}$ \\
\hline H-5a & $2.33-2.36$ & $\begin{array}{l}1 \mathrm{H}, \mathrm{dd}, J=1.40, \\
4.4\end{array}$ & $2.23-2.29$ & $2 \mathrm{H}, \mathrm{m}$ & $\begin{array}{l}2.32- \\
2.38\end{array}$ & $2 \mathrm{H}, \mathrm{m}$ \\
\hline $\mathrm{H}-5 \mathrm{~b}$ & $2.34-2.37$ & $\begin{array}{l}1 \mathrm{H}, \mathrm{dd}, J=1.25, \\
5.4\end{array}$ & & & & \\
\hline \multirow{5}{*}{$\begin{array}{l}\mathrm{H}-7 \\
\mathrm{H}-8 \\
\mathrm{H}-9 \\
\mathrm{H}-10\end{array}$} & $1.63-1.86$ & $3 \mathrm{H}, \mathrm{m}$ & & & $\begin{array}{l}1.64- \\
1.82 \\
\end{array}$ & $3 \mathrm{H}, \mathrm{m}$ \\
\hline & $1.63-1.86$ & \multirow[t]{4}{*}{$5 \mathrm{H}, \mathrm{m}$} & & & & \\
\hline & $1.50-1.57$ & & & & & \\
\hline & $1.39-1.47$ & & & & & \\
\hline & $1.31-1.36$ & & $1.24-1.93$ & $8 \mathrm{H}, \mathrm{m}$ & $\begin{array}{l}1.26- \\
1.34\end{array}$ & $5 \mathrm{H}, \mathrm{m}$ \\
\hline H-11 & 0.92 & $1 \mathrm{H}, \mathrm{t}, 7.1 \mathrm{~Hz}$ & 0.82 & $3 \mathrm{H}$, brs & 0.90 & $3 \mathrm{H}, \mathrm{t}, J=6.9 \mathrm{~Hz}$ \\
\hline
\end{tabular}

${ }^{\text {a) Data were recorded inCDCl}} 3$, at $500 \mathrm{MHz}$, multiplicities and coupling constants are given in $\mathrm{Hz}$; ${ }^{\text {b) }} \mathrm{CDCl}_{3}$, at $400 \mathrm{MHz}^{25}, \mathrm{CDCl}_{3}$, at $200 \mathrm{MHz}^{26}$.

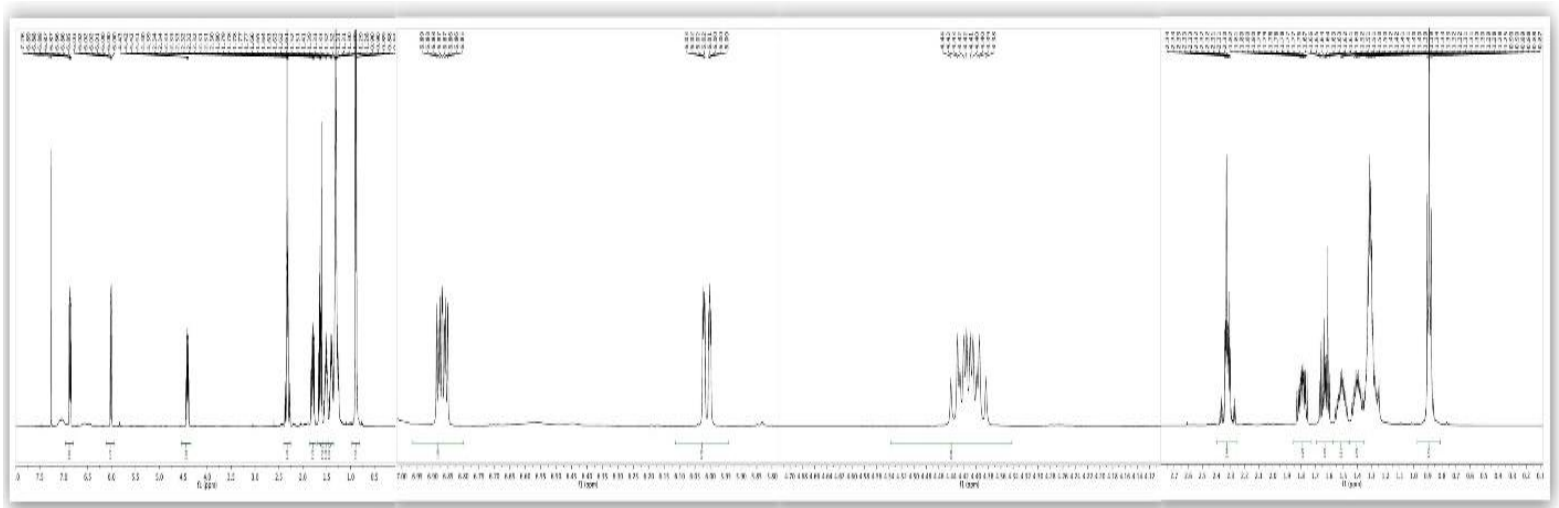

Figure. 5. ${ }^{1} \mathrm{H}-\mathrm{NMR}$ profile of massoia lactone.

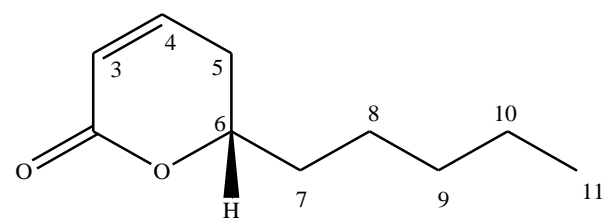

Figure. 6. Massoia lactone chemical structure.

\subsection{Effect of Massoialactone on microbial biofilms.}

Biofilm contaminations are a critical therapeutic concern since they are inconceivable to expel and cause a number of persistent infections. Anti-infective operators that are dynamic not as it were on cells but moreover on microbial biofilms are a basic target [47]. Essential oils are made up of a variety of organic compounds, some of which are considered to have antibacterial properties. Horse-tail lactone's efficacy on microbial biofilms was assessed using 
the MTT assay. Microorganisms with dynamic electron transport frameworks metabolize the yellow tetrazolium salt (MTT) and decrease it to water-soluble purple forma maz products in this assay. A microplate reader was used to calculate the color strength of soluble formazan maz on A550. Compared with the traditional antibacterial assay that counts bacteria on nutrient agar plates, the colorimetric assay using MTT is faster, more sensitive, and cheaper than XTT using tetrazolium dye. MTT has the downside of becoming a crystalline precipitate that must be dissolved prior to the absorbance calculation.

We discovered caudalide's anti-biofilm ability during our testing. Horse-tail lactone, the major compound isolated from aromatic tree bark essential oil, has anti-biofilm activity against a wide range of biofilms. A reduced level of biofilm formation relative to the control (biofilm without the test compound) was observed. C-10 Massoialactone was tested for antibiofilm action against single, double, and multi-species microbial biofilms. The results show that the median MBIC of C-10 Massoialactone is relative to the mesophase of a single species C. The biofilm concentrations of Candida albicans, Escherichia coli and Pseudomonas aeruginosa were $0.224 \% \mathrm{v} / \mathrm{v}, 0.231 \% \mathrm{v} / \mathrm{v}$ and $0.225 \% \mathrm{v} / \mathrm{v}$, while higher concentrations $(0.406 \% \mathrm{v} / \mathrm{v}$, respectively, $0.246 \% \mathrm{v} / \mathrm{v}(0.357 \% \mathrm{v} / \mathrm{v})$ to partially inhibit the mature stage of microbial single-species biofilm formation.

C-10 Massoialactone showed a 50\% inhibitory effect on the middle and maturation phases of dual-species $C$. albicans $-E$. coli at concentrations of $0.402 \% \mathrm{v} / \mathrm{v}$ and $0.290 \mathrm{v} / \mathrm{v}$, whereas against $C$. albicans- $P$. aeruginosa intermediate and mature phase biofilm formation, MBIC50 was shown at concentrations of $0.446 \% \mathrm{v} / \mathrm{v}$ and $0.167 \% \mathrm{v} / \mathrm{v}$, respectively. MBIC50 of C-10 Massoialactone against multi-species of $C$. albicans $-E$. coli $-P$. aeruginosa intermediate phase and mature phase biofilm was shown at concentrations of $0.532 \% \mathrm{v} / \mathrm{v}$ and $0.818 \% \mathrm{v} / \mathrm{v} ., 0.801 \% \mathrm{v} / \mathrm{v}$, respectively.

C-10 Massoialactone also was shown to be capable of disturbing $50 \%$ of preformed monospecies C. albicans concentration of $0.532 \% \mathrm{v} / \mathrm{v}$, E. coli biofilm concentration of $0.169 \%$ $\mathrm{v} / \mathrm{v}$ and $P$. aeruginosa biofilm at a concentration of $0.050 \% \mathrm{v} / \mathrm{v}$. Higher concentrations $(0.638 \%$ $\mathrm{v} / \mathrm{v}$ and $0.495 \% \mathrm{v} / \mathrm{v}$ ) were needed to disturb as much as $50 \%$ of dual-species (C. albicans $-E$. coli and C. albicans - P. aeruginosa) established biofilm. The concentration of C-10 Massoialactone needed to disturb 50\% multi-species (C. albicans- E. coli - P. aeruginosa) biofilm is at $0.801 \% \mathrm{v} / \mathrm{v}$.

Table 4. MBIC $_{50}$ Value of C-10 Massoialactone against Mono, Dual, Dan Multispecies Biofilm.

\begin{tabular}{l|l|l|l}
\multicolumn{1}{c|}{ Species } & $\begin{array}{c}\text { MBIC50 C-10 } \\
\text { Massoialactone } \\
\text { against intermediate } \\
\text { phase biofilm }\end{array}$ & $\begin{array}{c}\text { Massoialactone } \text { against } \\
\text { mature phase biofilm }\end{array}$ & $\begin{array}{c}\text { Massoialactone } \\
\text { MBE-10 }\end{array}$ \\
\hline Monospecies C. albicans & 0.224 & 0.406 & 0.532 \\
\hline Monospecies P. aeruginosa & 0.225 & 0.357 & 0.050 \\
\hline Monospecies E. coli & 0.231 & 0.264 & 0.169 \\
\hline $\begin{array}{l}\text { Dual-species C. Albican } \quad P . \\
\text { aeruginosa }\end{array}$ & 0.446 & 0.167 & 0.495 \\
\hline Dual-species C. albicans - E. coli & 0.402 & 0.290 & 0.638 \\
\hline $\begin{array}{l}\text { Multispecies C. albicans }- \text { E. coli } \\
- \text { P.aeruginosa }\end{array}$ & 0.532 & 0.818 & 0.801
\end{tabular}



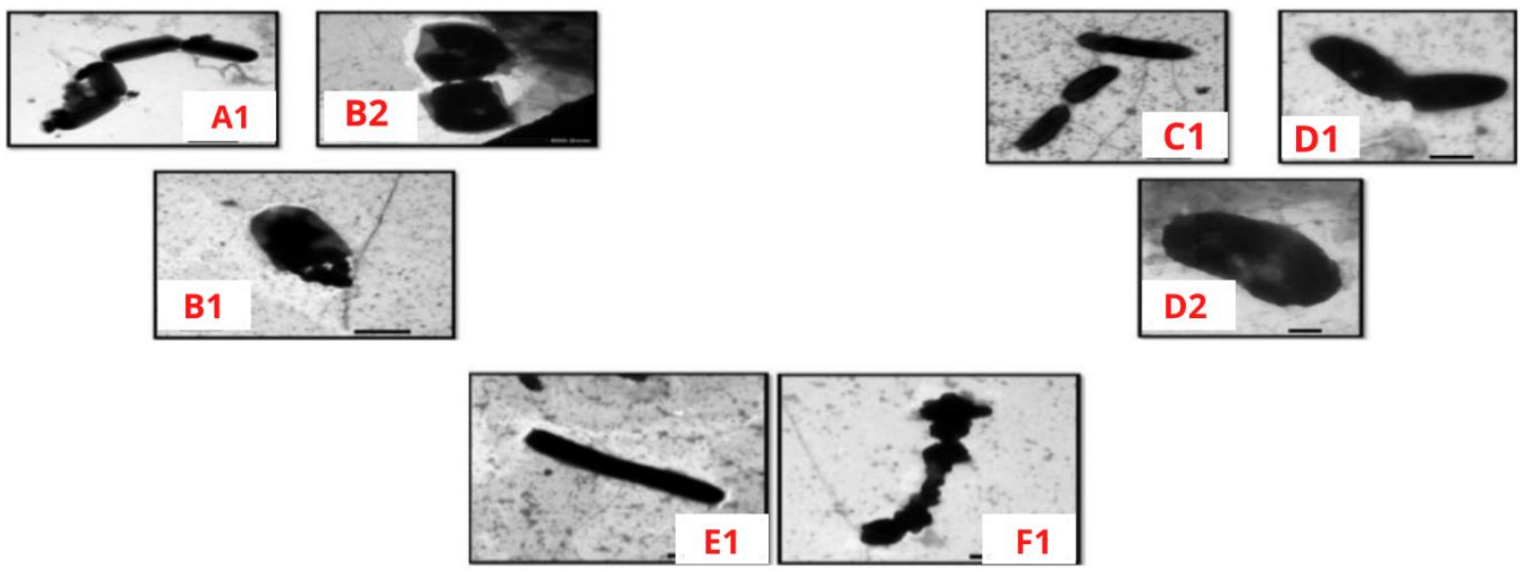

Figure 7. TEM analysis of mono species biofilm of $C$. albicans $(\mathbf{A 1}) ;$ E. coli $(\mathbf{C 1}) ;$ P. aeruginosa $(\mathbf{E 1 )}$ without the presence of C-10 Massoialactone. Mono species biofilm of C. albicans (B1, B2), P. aeruginosa (D1, D2), and $E$. coli $(\mathbf{F 1})$ with the presence of C-10 Massoialactone.

TEM analysis indicated that in biofilm on mono-species of C. albicans, E. coli, P. aeruginosa, after being given $0.5 \% \mathrm{v} / \mathrm{v}$ of C-10 Massoialactone, there was lysis of the cell wall, causing some damage and leakage of the cell. This condition might occur due to disruption of the peptidoglycan (murein), causing the peptidoglycan synthesis to be inhibited. Thus, it affects cells' integrity and could also contribute to the damage of the cytoplasmic membrane of bacteria. It made bacterial cells unable to metabolize, so as a result, lysis happens.

The result of SEM analysis of C. albicans biofilm by providing $0.5 \% \mathrm{v} / \mathrm{v} \mathrm{C}-10$ Massoialactone indicated that some cell damage was caused by the integrity of the host cell, preventing $C$. albicans from forming hyphae. It leads to a decrease in cell adhesion ability to the host due to the outbreak of the membrane of $C$. albicans. In $P$. aeruginosa, the cell's explosion is caused by the damage on the peptidoglycan of $P$. aeruginosa, a major component of the bacterial cell wall. Therefore, could not the judgment of the cells be maintained. In $E$. coli, a cell leakage was affected by the active compounds attacking and affecting the cytoplasmic membrane's integrity, initiating the leakage of intracellular material in the biofilm. Dual-species of C.albicans- E. coli and C.albicans- P. aeruginosa, after giving the C-10 Massoialactone, underwent cell shrinkage and cell damage. The cell damage is caused by an increase in the permeability of the membrane. Mature biofilms consist of yeast with hyphal elements forming complex tissues encased in the EPS matrix and away from the surface [48]. Thus it facilitates the entry of antibacterial components into the cells and causes cell damage. In multi-species biofilm of $C$. albicans- E. coli-P. aeruginosa, exposure to C-10 Massoialactone causes leakage of $C$. albicans cell, lysis of $P$. aeruginosa, and cell shrinkage of E. coli.
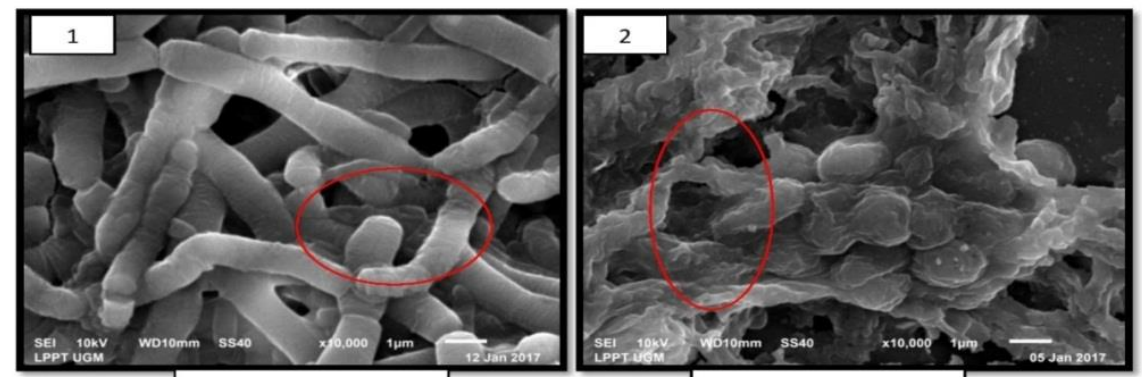

Figure 8. Scanning Electron Microscope (SEM) of dual-species C. albicans- E. coli biofilm. Without C-10 Massoialactone (1) and with the company of C-10 Massoialactone (2). 

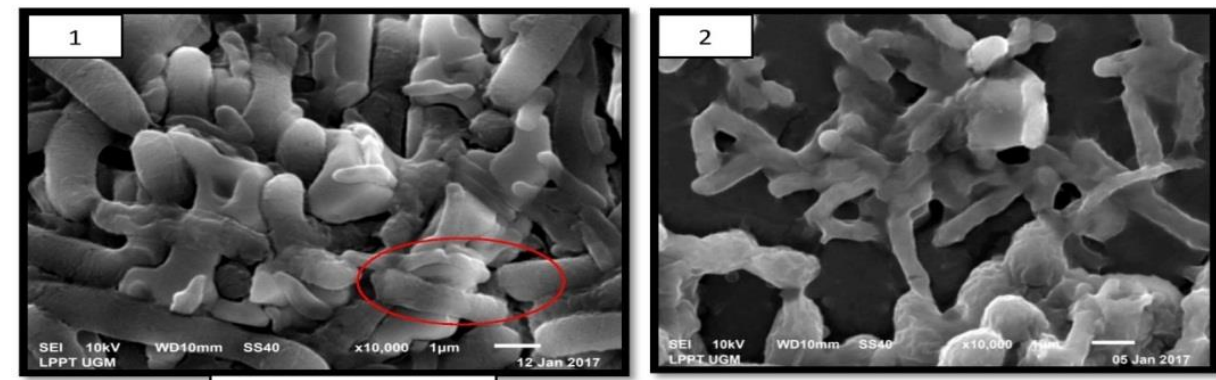

Figure 9. Scanning Electron Microscope (SEM) of dual-species C. albicans- P. aeruginosa biofilm. Without C10 Massoialactone (1) and with the company of C-10 Massoialactone (2).
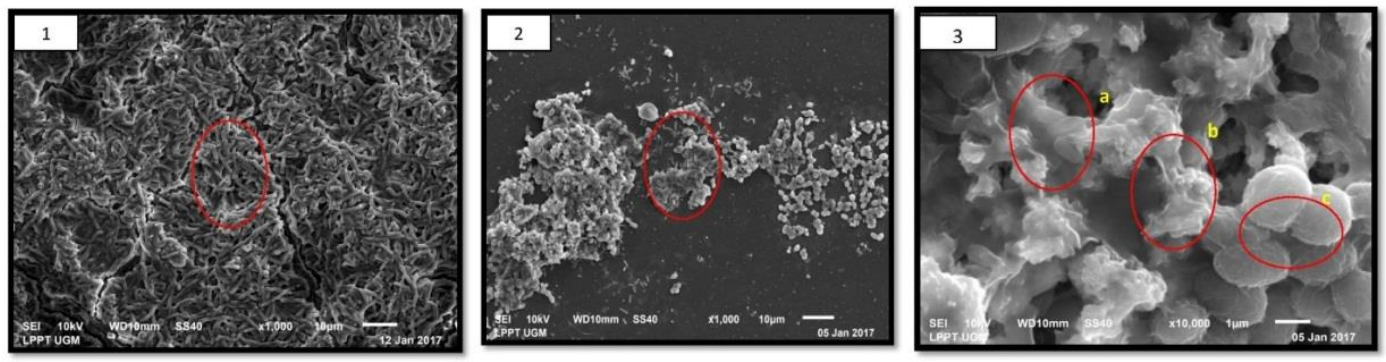

Figure 10. Scanning Electron Microscope (SEM) of multi-species (C. albicans - P. aeruginosa - E. coli) biofilm. Without the presence of C-10 Massoialactone $0,50 \% \mathrm{v} / \mathrm{v}(\mathbf{1})$, and with the presence of $0.5 \% \mathrm{v} / \mathrm{v} \mathrm{C}-10$ Massoialactone (2,3).

We have determined that the mechanism of action of lactones on microbial biofilms involves membrane destruction, which leads to changes in membrane permeability and leakage of intracellular substances. As shown by Cowan [49] and Trombetta et al. [50], This substance has the ability to infiltrate polysaccharide matrixes and remove lipids in biofilms. The cultivability and membrane integrity of Yarrowialipolyticalostost will be impaired in the presence of lactones, and the expansion of lactones to the culture medium will result in a decrease in ergosterol concentration [51]. However, Kishimoto et al. [52] conducted a report. Therefore, anti-biofilm agents that degrade the matrix and expose the bacteria in the biofilm to the environment can make the bacteria more sensitive to the host's immune system and antimicrobial agents [53]. Also, the EPS matrix on biofilms can help microorganism cells last longer than when they are in planktonic conditions so that it can help to microcortium various species of microorganisms in the degradation process [54]. This was caused by the more extended the biofilm growth time, the stronger the joint venture among the bacteria community, so the antibiotic was hard to penetrate [55]. It's thought that Massoialactone's anti-fungal properties derive from its capacity to block Candida albicans' respiratory system. It will save Candida albicans from absorbing oxygen. Since the exact mechanism of Massoialactone's antibiofilm action is unknown, further research into Candida albicans cell gene expression in response to Massoialactone is needed.

\section{Conclusions}

C-10 Massoialactone shows the potential activity as an inhibitor of the formation of mono-species and polymicrobial biofilms and degrades biofilms that have been formed. SEM analysis confirms the ability of compounds to interfere with extracellular polymer substances (EPS). C-10 Massoialactone can be a potential source of modern anti-biofilm drugs for an assortment of microbial biofilms. 


\title{
Funding
}

This research received no external funding

\section{Acknowledgments}

\begin{abstract}
The author would like to express his gratitude to the Microbiology Laboratory of the Faculty of Pharmacy, Gadjah Mada University, and Erika Nandini for their assistance in the preparation of this manuscript
\end{abstract}

\section{Conflicts of Interest}

The authors declare no competing interests.

\section{References}

1. Costerton, JW.; Stewart, PS.; Greenberg, EP. Bacterial Biofilms: A Common Cause Of Persistent Infections. Science 2012, 1318-22, https://doi.org/10.1126/science.284.5418.1318.

2. Hall-Stoodley, L.; Costerton, JW.; Stoodley, P. Bacterial Biofilms: From The Natural Environment To Infectious Disease. Nat Rev Microbiol 2004, 2, 95-108.

3. Tseng, YK.; Yu, CC.; Chien, JH.; Fu,SD. Evaluation Of Biofilm Formation In Candida Tropicalis Using A Silicone-Based Platform With Synthetic Urine Medium. Microorganisms 2020, 8, https://doi.org/10.3390/Microorganisms8050660.

4. Wagner, EM.; Nadja,P.; Sarah,T.; Katharina, F.; Nicole, R. International Journal Of Food Microbiology Identi Fi Cation Of Bio Fi Lm Hotspots In A Meat Processing Environment : Detection Of Spoilage Bacteria In Multi-Species BioFilms. International Journal Of Food Microbiology 2020, 328, 108668, https://doi.org/10.1016/j.ijfoodmicro.

5. Alam.; Khan.; Dunia, A.; Syeda, M.E.F.; Muhammad, A.; Mohamed, S.; Roua, M.A.; Abd, E.Z.; Mustafa. Anti-Biofilm Activity Of Plant Deriv ed Extracts Against Infectious Pathogen- Pseudomonas Aeruginosa PAO1. Journal Of Infection And Public Health 2020, 13, 1734-41, https://doi.org/10.1016/j.jiph.2020.07.007.

6. Zhang.; Lulu.; Enjun .L.; Yungchi, C.; Tariq, M.; Feng, G.; Ke, Z.; Mei, B. Biomedicine \& Pharmacotherapy Is Combined Medication With Natural Medicine A Promising Therapy For Bacterial Biofilm Infection. Biomedicine \& Pharmacotherapy 2020, 128, https://doi.org/10.1016/j.biopha.2020.110184.

7. Melo.; D R, Graça, P.; Fernando, O.; Diana, V.B.; Carina, A.; Sanna, S.; Nuno, C.; Joana, A. Viruses The Protective E Ff Ect Of Staphylococcus Epidermidis Biofilm Matrix Against Phage Predation. Viruses 2020, 12, 1-13, https://doi.org/doi:10.3390/v12101076.

8. Horton.; Mark, V.; \& Jeniel, N. Candida auris infection and biofilm formation: going beyond the surface. Curr Clin Microbiol 2020, 7, 51-56, https://doi.org/10.1007/s40588-020-00143-7.

9. Kalimuthu.; Shanthini.; Becky, P.K.C.; Joyce, Y.; Karthi, S.; Adline, P.S.; Prasanna, N. A Novel Small Molecule, 1, 3-Di-M-Tolyl-Urea, Inhibits And Disrupts Multispecies Oral Biofilms. Microorganisms Article 2020, 8, 1-12, https://doi.org/10.3390/microorganisms8091261.

10. Abebe.; Gedif, M. The Role Of Bacterial Biofilm In Antibiotic Resistance And. International Journal Of Microbiology 2020, 10, 1-9, https://doi.org/10.1155/2020/1705814.

11. Furukawa S.; Kuchma, S.L.; O’Toole, G.A. Keeping Their Options Open: Acute Versus Persistent Infections. J Bacteriol 2006, 188, 1211-1217.

12. Hamzah.; H., Pratiwi.; S.U.T., Hertiani. T. Efficacy Of Thymol And Eugenol Against Polymicrobial Biofilm. Indonesian J. Pharm 2018, 29, 8, https://doi.org/10.14499/indonesianjpharm29iss4pp221.

13. Bose.; Rahul.; Konstantinos, I.; Federico, F.; Abdulaziz, B.; Robert, D.K.; Sanjukta, D.; Francesco, M.; Sadia, A.N. "Antimicrobial Effectiveness Of Calcium Silicate Sealers Against A Nutrient-Stressed Multispecies Biofilm. "Journal Of Clinical Medicine Article 2020, 9, 1-15. https://doi.org/doi:10.3390/jcm9092722.

14. Wu.; Xiaojuan.; Dunia, A.A.; Jayarajapazham, R.; Roua, M.A.; Ponnuswamy, V.; Noorah, A.A.; Agastian, P.; Maryam, K.A. Saudi Journal Of Biological Sciences Characterization Of Biofilm Formed By Multidrug Resistant Pseudomonas Aeruginosa DC-17 Isolated From Dental Caries. Saudi Journal Of Biological Sciences 2020, 27, 2955-60, https://doi.org/10.1016/j.sjbs.2020.07.020.

15. Liu, H.; Xu, L.; Zeng, J. Role Of Corrosion Products In Biofilms In Microbiologically Induced Corrosion Of Carbon Steel. British Corr J. 2000, 35, 131-135.

16. Tyfa.; Agnieszka. Alicyclobacillus Acidoterrestris Biofilm On. Article 2020, 25, 3334, 1-11, https://doi.org/0.3390/molecules25153334. 
17. Marsh, P.D.; Bradshaw, D.J. Dental Plaque As A Biofilm. J Ind Microbiol. 2005, 15, 169-75.

18. Yao.; Yuan.; Yang, P.; Wing, Y.N.; Karin, K.; Jie. P, Meng, L.; Olivier, H. Effects Of Sodium Citrate On The Structure And Microbial Community Composition Of An Early-Stage Multispecies Biofilm Model. Scientific Reports 2020, 10, 1-10, https://doi.org/10.1038/S41598-020-73731-8.

19. Watnick PI.; Kolter R. Steps In The Development Of A Vibrio Cholera El Tor Biofilm. Molmicrobiol 1999. 34, 586-595.

20. Aires.; Andreia.; António, S.B.; Teresa S.L. Antimicrobial Effects Of Essential Oils On Oral Microbiota Biofilms: The Toothbrush In Vitro Model. Antibiotics 2021, 10, 1-16, https://doi.org/10.3390/Antibiotics10010021.

21. Harrison.; Freya.; Raymond, N.A.; Sarah E. M. Editorial : Polymicrobial Bio FiLms In Chronic Infectious Disease Frontiers In Cellular And Infection. Microbiology 2020, 10, 1-2, https://doi.org/10.3389/Fcimb.2020.628584.

22. Petruzzi.; Briana.; Allan, D.; Kevin, L.; William K.; Scarratt.; Thomas, J.I. Polymicrobial Biofilm Interaction Between Histophilus Somni And Pasteurella Multocida. Frontiers In Microbiology 2020, 11, 1-14, https://doi.org/10.3389/Fmicb.2020.01561.

23. Frisan; T. Co- And Polymicrobial Infections In The Gut Mucosa: The Host-Microbiota-Pathogen Perspective. Cellular Microbiology 2021, 23, 1-9, https://doi.org/10.1111/Cmi.13279.

24. Archer, N.K.; Mazaitis, M.J.; Costerton, J.W.; Leid, J.G.; Powers, M.E.; Shirtliff, M.E. Staphylococcus Biofilms: Properties, Regulations, And Roles In Human Disease, Virulence 2011, 2, 445-459, https://doi.org/10.4161/viru.2.5.17724.

25. Sateriale.; Daniela.; Roberta, I.; Roberta, C.; Chiara, P.; Ettore, V.; Maria, G.V.; Paola, S.; Marina, P.; Caterina, P. Phytocompounds Vs Dental Plaque Bacteria: In Vitro Effects Of Myrtle And Pomegranate Polyphenolic Extracts Against Single-Species And Multispecies Oral Biofilms. Frontiers In Microbiology 2020, 11, 1-15, https://doi.org/10.3389/Fmicb.2020.592265.

26. Lee, J.H.; Lee, J.S.; Chung, M.S.: Kim, K.H. In Vitro Anti-Adhesive Activity Of An Acidic Polysaccharide From Panax Ginseng On Porphyromonasgingivalis Binding To Erythrocytes. Planta Med. 2004, 70, 566568, https://doi.org/10.1055/s-2004-827160.

27. Kadam.; Snehal.; Vandana, M.; Anuradha, B.; Karishma, S.K. From Treatise To Test: Evaluating Traditional Remedies For Anti-Biofilm Potential. Frontiers In Pharmacology 2020, 11, 1-11, https://doi.org/10.3389/Fphar.2020.566334.

28. Batoni.; Giovanna.; Giuseppantonio, M.; Semih, E. Therapeutic Potential Of Antimicrobial Peptides In Polymicrobial Biofilm-Associated Infections. International Journal Of Molecular Sciences 2021, 22, 482, https://doi.org/10.3390/Ijms22020482.

29. Nitis, I.M. Country Pasture/Forage Resources Profiles Indonesia. In: Reynolds, S.G. (Ed.), Food And Agriculture Organization Of The United Nations Report Indonesia: Agriculture Sector 2014.

30. Gunawan, D. Ramuan tradisional untuk keharmonisan suami istri. Depok-Indonesia: PT Penerbitswadaya; 1999, 46-47.

31. Guenther E. The Essential Oils. Huntington, New York: Robert E Kliger Publishing Co. Inc.; 1987

32. Id.; Nurul, J.; Erwin, K.; Chusnul, E.; Safitri, H. An Ethnobotanical Study Of Medicinal Plants Used By The Tengger Tribe In Ngadisari Village, Indonesia. Plosone 2020, 1-16, https://doi.org/10.1371/Journal.Pone.0235886.

33. Hapsari Y.; Simanjuntak, P. Study Of Chemical Compound In Ethyl Acetate Extract Phase Of Cinnamomum Spp. By HPLC And GC-MS. J Kimia Mulawarman 2010, 8, 23-27.

34. Lily, P. Medicinal Plants Of South East Asia. Massachusetts, USA: MIT Press 2005.

35. Bustanussalam.; Susilo H.; Nurhidayati, E. Identifikasi Senyawadan Uji Aktivitas ekstrak Etil Asetat Kulit Kayu Massoi (Cryptocarpamassoy). Fitofarmaka 2012, 2, 67-76.

36. Widowati L.; Pudjiastuti. Khasiat analgetika kulit batang masoyi (Massoiaaromaticumbecc.) Pada mencit putih. Warta Tumbuh anobat Indonesia. 1999, 5, 11-12.

37. Sa'roni.; Adjirni. Efek. antiinflamasi kulit batang massoiaaromaticumbecc. (Masoyi) Pada tikus putih. Warta Tumbuhanobat Indonesia. 1999, 5, 9-10.

38. Pratiwi SUT.; Lagendijk, E.L.; De, W.S.; Hertiani, T.; Idroes, R.; Van, D.H. Effect Of Cinnamomumburmanniinees Ex Bl. And Massoiaaromaticabecc. Essential Oils On Planktonic Growth And Biofilm Formation Of Pseudomonas Aeruginosa And Staphylococcus Aureus In Vitro. International Journal Of Applied Research In Natural Products 2015, 8, 1-13.

39. Pratiwi SUT.; Hertiani, T. Efficacy Of Massoia Oil In Combination With Some Indonesian Medicinal Plants Oils As Anti-Biofilm Agent Towards Candida Albicans. Int J Pharm Sci Res 2017, 8, 25, https://doi.org/10.13040/IJPSR.0975-8232.8(5).2013-25.

40. Wagner H.; Bladt S. Plant Drug Analysis A Thin Layer Chromatography Atlas, $2^{\text {nd }}$ Ed. Berlin: Springer. 1996.

41. Horvath, G.; Szabó, L.G.; Lemberkovics, E.; Botz, L.; Kocsis, B. Characterization And TLCBioautographic Detection Of Essential Oils From Some Thymus Taxa, Determination Of The Activity Of The Oils And Their Components Against Plant Pathogenic Bacteria. J Planar Chromatogr 2004, 17, 300304. 
42. Wu, X.; Zhao, M.; Wang, J.; Cui, C.; Wu, J.; Yang, B. Effects Of Cooking Conditions On Sensory Characteristics Of Red-Cooked Beef Flavor And Identification Of The Flavor Compounds. J. Food Process Eng 2008, 31, 51-65.

43. Trafny, E.A.; Lewandowsky, R.; Zawistowska, M.I.; Stepińska, M. Use Of MTT Assay To Determine The Biofilm Formation Capacity Of Microorganisms In Metalworking Fluids. World J. Microbiol Biotechnol 2013, 29, 1635-1643.

44. Pierce, C.G.; Uppuluri, P.; Tristan, A.R.; Wormley, F.L.; Mowat, E.; Ramage, G. A Simple And Reproducible 96 Well Plate-Based Method For The Formation Of Fungal Biofilms And Its Application To Anti-Fungal Susceptibility Testing. Nat Protoc 2008, 3, 1494-1500.

45. Simionatto, E.; Carla, P.C.; Stüker, C.Z.; Dalcol, I.I.; Da, S.U. Chemical Composition And Anti-Microbial Activity Of The Essential Oil From Aeolanthussuaveolens Mart. Ex Spreng Quím Nova 2007, 30, http://Dx.Doi.Org/10.1590/S0100-40422007000800024.

46. Harbinger, A.; Kumar, P. Organocatalytic Enantioselective Approach To The Synthesis Of Verbalactone And (R)-Massoialactone. Synthesis 2011, 12, 1954-1959.

47. Schillaci, D.; Arizza, V.; Dayton, T.; Camarda, L.; Di, S.V. In Vitro Anti-Biofilm Activity Of Boswellia Spp. Oleogum Resin Essential Oils. Lett App Microbiol 2008, 47, 433-438.

48. Hamzah, H.; Yudhawan, I.; Rasdianah, N.; Setyowati, E., Nandini; Utami, S. Clove Oil Has the Activity to Inhibit Middle, Maturation and Degradation Phase of Candida Tropicalis Biofilm Formation. Biointerface Reserch in Applied Chemistry 2020, 12, 1507-1519, https://doi.org/10.33263/BRIAC122.15071519.

49. Cowan, M.M. Plant Products As Antimicrobial Agents. Clin Microbiol Rev. 1999, 12, 564-582.

50. Trombetta, D.; Castelli, F.; Sarpietro, M.G.; Venuti, V.; Cristani, M.; Daniele, C. Mechanisms Of Antibacterial Action Of Three Monoterpenes. Antimicrobial Agents Chemother. 2005, 49, 2474-2478.

51. Ngoc, T.M.; Cao, H.L.; Phan, T.H.; Tran, H.D.; Souffou, N.; Gresti, J. New Insights Into The Effect Of Medium-Chain-Length Lactones On Yeast Membranes, Importance Of The Culture Medium. App Microbiol Biotech 2010, 87, 1089-1099.

52. Kishimoto N.; Sugihara, S.; Mochida, K.; Fujita, T. In Vitro Anti-Fungal And Antiviral Activities Of $\Gamma$-And $\Delta$-Lactone Analogs Utilized As Food Flavoring. Biocontrol Sci 2005, 10, 31-36.

53. Pirlar.; Rima, F.; Mohammad, E.; Reza, B.; Maryam, B.; Willem, B.; Van, L.; Fereshteh, J.I. Combinatorial Effects Of Antibiotics And Enzymes Against Dual-Species Staphylococcus Aureus And Pseudomonas Aeruginosa Biofilms In The Wound-Like Medium. Plosone 2020, 1-19, https://doi.org/10.1371/Journal.Pone.0235093.

54. Hamzah, H.; Hertiani, T.; Pratiwi, S. U. T., \& Nuryastuti, T. Efficacy of quercetin against polymicrobial biofilm on catheters. Research Journal of Pharmacy and Technology 2020, 13(11), 5277-5282, https://doi.org/10.5958/0974-360X.2020.00923.3.

55. Pratiwi, S. U. T., \& Hamzah, H. Inhibition and degradation activity of (Sapindus rarak seeds) ethanol extract against polymicrobial biofilm. Research Journal of Pharmacy and Technology 2020, 13(11), 5425-5430, https://doi.org/10.5958/0974-360X.2020.00947.6. 